\title{
Family Models for Earning and Caring: Implications for Child Care and for Family Policy
}

\author{
Roderic Beaujot ${ }^{1}$ \\ University of Western Ontario \\ rbeaujot@uwo.ca
}

\author{
Zenaida R. Ravanera \\ University of Western Ontario \\ ravanera@uwo.ca
}

\begin{abstract}
Canadian families have changed, in part due to an economy that provides more work opportunities for women, and a cultural orientation that values equal opportunity and diversity in families. In spite of the change, both quantitative and qualitative evidence suggest a continued preference for mothers to spend considerable time with children, especially in the infant and toddler years. Thus, in an average couple, the presence of young children in the home brings wives to reduce their paid work and husbands to increase their paid work. Our reading of parental preferences suggests an interest in more services for young children in the form of early childhood education and child care, but also an interest in policies that would allow parents to spend more time with children through parental leaves, part-time work with good benefits, and subsidies that supplement market income. Many options available to two-parent families are often less feasible for lone parents, giving a higher priority to child care.
\end{abstract}

Keywords: work opportunities for women, family diversity, child care, family policy

\section{Résumé}

La famille canadiennes a changé, dû en partie à une économie qui offre plus de possibilités d'emploi pour les femmes, et à une tendance culturelle qui valorise l'égalité des chances et la diversité dans les familles. En dépit de ces changements, les preuves quantitatives et qualitatives suggèrent une préférence continue pour les mères de passer plus de temps avec les enfants, particulièrement quand il s'agit de nouveau-nés ou d'enfants en bas âge. Donc, pour un couple moyen, la présence de jeunes enfants au foyer pousse les femmes à réduire leurs emplois rémunérés et les maris à augmenter les leurs. Notre étude des préférences parentales suggère

1. Acknowledgement: The authors are indebted to Don Kerr, Eric Tenkorang, and Mustafa Zahid for their generous help with this paper. 
un intérêt pour un accroissement des services pour jeunes enfants sous la forme d'éducation préscolaire et de garde d'enfants, et aussi un intérêt pour des politiques qui permettraient aux parents de passer plus de temps avec leurs enfants tels que congés parentaux, emplois à temps partiel avec de bonnes prestations, et subventions pour supplémenter les salaires. Beaucoup d'options qui sont disponibles aux familles biparentales sont souvent moins réalisables pour les familles monoparentales, ce qui accorde une plus grande priorité aux services de garde d'enfants.

Mots clés : possibilités d'emploi pour les femmes, diversité des familles, garde d'enfants, politiques familiales.

\section{Earning and Caring in the Human Life Course}

Earning a living and caring for each other are the core activities that define families as units of material and emotional interdependence, and families typically depend on assistance from a broader social group beyond the immediate parents, at least for families with young children. It is not just in modern times that parents need help from relatives or the broader society in caring for children. For instance, primatologist Hrdy (2006:50-51) observes that humans have always been "co-operative breeders, with childcare shared between different members of the society" (see also Kaplan, 1997; Lahdenpera et al., 2004; Lee and Kramer, 2002).

While there has always been a need for assistance from a broader social group for care of children, the manner of assistance differs across the situations of families and societies. To understand the current situation in Canada, the demographics of child care need to pay attention to changes in the family and the variety of ways in which earning and caring occur in families. Thus, in this paper, we discuss the changes in families with particular focus on gender and the interpretation of these changes from economic and cultural perspectives. Using data from the 2001 census and from surveys, we examine parents' behaviour and preferences for work and child care. On the basis of parental behaviour, their perceived needs, and preferences, we then reflect on the various ways by which policies could support care for children.

Our purpose is to summarize and interpret family change and diversity across families, especially in terms of earning and caring activities, in order to reflect on priorities for policies supporting families with young children. We propose that change and diversity in earning and caring, due to economic and cultural factors, bring a need for diversity in types of family support. When earning and caring activities are divided along traditional lines, policy can focus on "breadwinner benefits" including provisions in the case 
of death or disability of the breadwinner. The large increase in the number of two-earner families brings attention to questions of parental leave, child care, and work-life balance. The diversity associated with larger numbers of parental separations calls for special provisions for one-parent families.

\section{Interpreting Change in Gender and Families from Economic and Cultural Perspectives}

The main economic changes that have had an impact on the family and on gender are the growth of the service sector, the evolution of a 24 hour economy, the greater need for advanced skills, and the increase in nonstandard jobs. These have enhanced opportunities for women in the paid labour force. Women have increased their education and have been well positioned to take advantage of these economic changes. Bachelor's degrees probably present more relative advantages for women than for men, given the jobs that are available (Bouchard and Zhao, 2000; Drolet, 2002b; Boothby and Drewes, 2006). In contrast, young men have been disadvantaged in the labour market, at least when compared to older men (Morissette, 1998; Picot, 1998).

In spite of greater participation of women in the labour force, there remain considerable differences in the occupational profiles of women and men. Women retain the advantage of working in less dangerous conditions (Marshall, 1996). They are more likely to be in jobs that offer greater flexibility, which includes public sector jobs and nonstandard work. In comparison to jobs in business or law, jobs in teaching or nursing have greater potential for leave taking and working part-time to accommodate childbearing (Ranson, 1998, 2005). Clearly, this greater flexibility comes with the cost of lower pay.

Other economic changes have to do with productivity within the home. In More than a Labour of Love, Luxton (1980) shows that the "first generation" of women in Flin Flon Manitoba were completely occupied with labour in the home. Washing and ironing were a full day's work; it took much time to heat the home, to obtain and store food from gardens, and to prepare meals. Becker (1991) has proposed that a household is most efficient when one person spends time in the market and another in home production. This division of roles results in efficiency gain when work in the market and in the home each involve a full-time job. But, as work within the home has become less than a full-time job, this gain is reduced, and advantages arise from other forms of division of labour, including greater participation of women in the market and greater sharing of unpaid work within couples. 
It is not just economic changes that have altered the context of gender and families. On the cultural side there has been an interest to set patriarchy aside. The second generation of feminism has sought to ensure that biology would not be destiny, and that women would have equal opportunities, in the public sector and in the home (see for instance Royal Commission on the Status of Women, 1970). In his study of values, Nevitte (1996) sees an ideological shift that favours tolerance and egalitarian relationships, between spouses, and between parents and children. There are new ideals of less rigid gender models, of greater symmetry in the division of work, and even of mutuality by sharing in caring activities.

While greater involvement of women in paid work is partly motivated by economic necessity or the achievement of a desired standard of living, there is also a cultural push for equality and equal opportunity. This is seen in the shift in women's attitudes about work and family. For instance, Ravanera and Rajulton (2006) find that, in comparison to older women, younger women are more likely to want both work and family. This cultural change also includes a push for men's greater involvement in caring activities. Coltrane (1995) sees a continued increase in men's unpaid work in the home.

However, while there has been a general shift in favour of egalitarian relationships and toward greater symmetry in the division of paid and unpaid work, diversity remains. Hakim (2003) proposes that women may be categorized into three groups on the basis of their preferences: work-centred, family-centred, and adaptive. She suggests that some $60 \%$ of women are adaptive in the sense that they do not want to be completely work-centred nor family-centred, another $20 \%$ are work-centred (often with no children) and $20 \%$ are family-centred. Furthermore, the preferences could be modified by individual circumstances, in particular, by the presence of children. Based on the theory that gender differences occur through social relations, Fox (2001) found that, while $60 \%$ of the new mothers in a small Toronto sample returned to work within a year, there was a dominant pattern of "intensive mothering" in the first few months of the child's life. These new mothers felt that a partner was absolutely essential to the fulfilment of their responsibilities as mothers.

In effect, there are several coexisting models of division of work. In the complementary roles model, achieved characteristics are mostly important for men's marriage prospects because they have the main responsibility for generating family income (Becker, 1991). In the Oppenheimer $(1988 ; 1997)$ model of marriage, the achieved characteristics of both men and women are important to marriage, and there is divided responsibility for earning. Using data from American longitudinal surveys, Sweeney (2002) finds evidence 
for both models, with somewhat more evidence for the Oppenheimer model in the younger cohort. In particular, men's income is a significant predictor of marriage, while women's income is significant only for the younger cohort born in 1961-65. Similarly, the findings from a study by Drolet (2002a; 2003), using data from the Canadian Survey of Labour and Income Dynamics, could be interpreted as supporting both models. For older cohorts of women, marriage and motherhood had no association with wages, whereas for the youngest women, those who were married and those who postponed childbearing had higher wages.

\section{Parental Behaviour: Paid Work by Gender and Parental Status}

As a consequence of these economic and cultural changes, the employment/population ratio has converged considerably between women and men. Men's employment ratios have declined since 1981 and women's have increased since 1971. Among the OECD countries, Canada is exceptional for the amount of change between 1960-1990 (Engelhardt and Prskawetz, 2004:38). In 1960, with $32 \%$ of women in the labour force, Canada was among the countries with the lowest participation; in 2000, the rate of $71 \%$ puts Canada in the group with the highest participation.

While the trends for women and men are converging, parenthood still has the opposite average effect; that is, it leads to divergence of the employment patterns of women and men. Women with children at home are less likely to work full-time and the younger the child the less likely they are to be working full-time. The opposite occurs for men who are more likely to work full-time if they have children at home. There are similar findings with regard to work interruptions, which are more likely for women when they have children, but less likely for men who have children (Cook and Beaujot, 1996). As can be seen in Table 1, the situation has not changed much in 2001. Among men, the proportion working full-time is highest for those with children - slightly over $90 \%$ among men with children 14 years or younger. Among women, the proportion working full-time is lowest among those without children (at $48 \%$ ) but the proportion among those with children under 6 is not much higher at $49.7 \%$.

A finding that stands out in Table 1 is that for men and women with children at home, it is the never married who are least likely to work fulltime, and most likely to be not employed. A selection effect is a possible explanation; that is, those who are unemployed are less likely to marry or to cohabit - an explanation that probably holds more for men. But another 
explanation is that the presence of children is a greater constraint towards having a job when one has no partner. As seen in Table 1, the least amount of market work occurs for the never married, where $38.5 \%$ of women with children under six are not employed, compared to about $25 \%$ among married and cohabiting women. As shown by Neill (2004:6) the differences are stronger when the children are aged 0-3 years, where in $2002,46.7 \%$ of mothers in one-parent families were working compared to $64.1 \%$ in twoparent families. Higher education and more labour force participation have contributed to the income gains for lone parents in the period 1981-2001 (Galarneau, 2006).

The analysis by marital status (in Table 1) also shows that women with children at home are more likely to work full-time when they are in cohabit-

Table 1: Proportion (\%) Working Full-Time, Part-Time and not Employed by Sex, Presence of Children, Marital Status, Canada, 2001

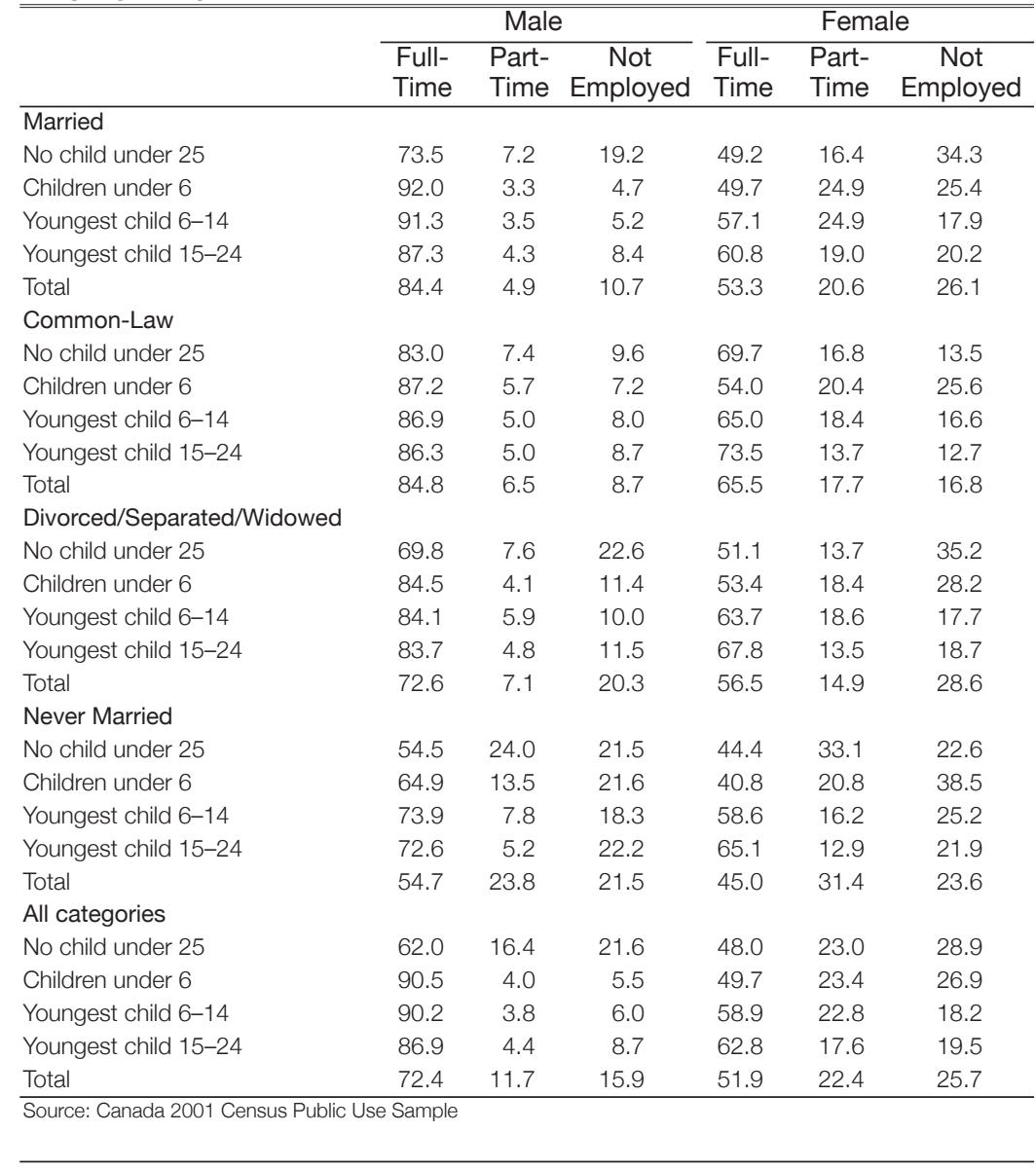


ing union or in postunion status than when they are married. Among women with children under 6 years, $49.7 \%$ of married and about $54 \%$ of cohabiting, and divorced/separated/widowed women are working full-time. The differences are greater among women with older children. These differences by marital status imply that traditional division of work is more likely to occur for married women than for women in cohabiting unions or in postunion status. Le Bourdais and Lapierre-Adamcyk (2004) theorize that cohabitation, as an alternative form of union, is less based on a traditional division of labour and its associated dependencies.

As further discussed in the next section, these relationships of work and parenting indicate the persistence of certain elements of the complementary roles model of family division of labour. In an American study, for example, the average tendency was for childbirth to reduce women's work time and to increase men's average wage (Lundberg and Rose, 2000). Couples in which wives interrupted their careers for child-rearing showed increased task specialization associated with childbirth, including a reallocation of time of both partners, and declines in wages of wives. However, for couples where the wife participated continuously in the labour market, the hours worked declined for both fathers and mothers but the wages of mothers did not decline with the birth of a first child. That is, the increase in task specialization associated with childbirth was less applicable to younger cohorts and to the subsample of couples in which wives continuously participated in the labour force. As the model of continuous participation in the labour force becomes dominant, the authors see converging time-use patterns for husbands and wives and a declining wage differentiation associated with parenthood.

\section{Models of Earning and Caring}

Time use data provide an opportunity for understanding these different family models. On the basis of the 2005 time-use survey, couples were categorized according to their division of paid and unpaid work (Beaujot and Liu, 2005; Beaujot, Ravanera and Liu, 2008). The advantage of time-use is that it adopts the same unit of measurement of earning and caring activities, that is, the time spent in these activities. Compared to the wife, the husband could be doing more paid work, less paid work, or the same amount of paid work. Similarly, the husband could be doing more, less, or the same amount of unpaid work. We have taken between $40-60 \%$ of the total time spent by the couple as indicating the same amount of time spent for an activity. Thus if together the couple spend 100 hours of unpaid work, the husband would be doing less than the wife if he does under 40 hours, more if he spends over 
60 hours, and the same if he does between 40 and 60 hours. Using these measures of relative sharing of paid and unpaid work, models of division of paid and unpaid work can be derived. As seen in Table 2, the proportions in the models have changed over the period 1992-2005, with decreases in the complementary traditional model and increases in the shared role model.

For 2005, Table 2 shows that the complementary-traditional (he does more paid work, she does more unpaid work) is the predominant model with $32.9 \%$, followed by woman's double burden (she is doing same amount of, or more, paid work, and more unpaid work) with $26.8 \%$. But there are those who follow the reverse models as well; that is, the complementary-genderreversed (she does more paid work, he does more unpaid work) comprises $3.0 \%$, and the men's double burden (he is doing same amount of, or more, paid work, and more unpaid work), $10.7 \%$. The role-sharing model, in which they do the same amount of unpaid work, comprises $26.5 \%$.

The complementary-traditional is more common when there are younger children and when there are more children in the home (Beaujot, Ravanera and Liu, 2008). Women's double burden is most common when there are no children, or when children are older; men's double burden is also more common when there are no children. These two findings taken together imply that the amount of unpaid work that needs to be done is one of the determinants of models of the division of work - when there is a great amount of unpaid work to be done, as when there are children, task specialization is more common, and women do more of the unpaid work. When the amount of unpaid work is reduced by the absence of children, double burden (of either men or women) is more likely.

Table 2: Models of the Division of Paid and Unpaid Work, 1992, 1998, and 2005

\begin{tabular}{lrrr}
\hline Model type & 1992 & 1998 & 2005 \\
\hline Total respondents & & & \\
Complementary-traditional & 43.5 & 39.1 & 32.9 \\
Complementary-gender-reversed & 1.7 & 2.7 & 3.0 \\
Women's double burden & 26.5 & 26.8 & 26.8 \\
Men's double burden & 5.8 & 7.6 & 10.7 \\
Shared roles & 22.6 & 23.8 & 26.5 \\
Total number of cases & 3518 & 3595 & 8360 \\
\hline
\end{tabular}

Definitions of models of the division of earning and caring activities

Complementary-traditional: wife is doing more unpaid work and husband more paid work.

Complementary-gender-reversed: husband is doing more unpaid work and wife more paid work.

Women's double burden: wife is doing the same amount of, or more, paid work, and more unpaid work.

Men's double burden: husband is doing the same amount of, or more, paid work, and more unpaid work.

Shared roles: wife and husband doing the same amount of unpaid work.

Source: Tabulated from the General Social Surveys on Time Use in 1992, 1998, and 2005.

Note: The table includes respondents where neither partner is retired nor a full-time student. There is a sample loss

of $11.0 \%$, representing persons who did not respond to these questions on weekly estimates for self and spouse. 
The role-sharing model of $26.5 \%$ shown in Table 2 is an indication (also implied in Table 1) that men's taking on an equal share of unpaid work is not yet as widespread as the complementary-traditional. This model is most common when both are working full-time (Beaujot, Ravanera, and Liu, 2008). Risman and Johnson-Sumerford (1998) have called this role sharing model a "postgender marriage." For the most part, their qualitative studies, along with those by Hochschild (1989) and Fox and Fumia (2001) have seen the role sharing model as a deliberate attempt by couples to achieve a more egalitarian relationship.

\section{The Child Care Situation}

Economic and cultural changes have brought about not only greater diversity of family types and models of earning and caring, but also diversity in the manner of caring for children. Based on data from the National Longitudinal Survey of Children and Youth (NLSCY), Table 3 shows the proportions in various care situations for children under six. As with other similar tabulations, this shows much diversity in the care situations, with many children in more than one situation, and with differences in types of child care by work status and family structure. For the total population of children aged $0-5$ in 2002/03, 52.3\% were in some child care situation for at least part of the day. The most common form of child care was in someone else's home by a nonrelative, which amounts to $18.4 \%$ of all children under six, while another $13.5 \%$ received care by a relative in someone else's home. The second most important category is care in a daycare centre, amounting to $15.7 \%$ of children under six in Canada as a whole.

As there are differences in availability of affordable daycare facilities, Table 3 distinguishes between Quebec and the rest of Canada in child-care use for children under six. The differences are significant, with total care amounting to $65.1 \%$ of children in Quebec, compared to $48.7 \%$ in the rest of Canada. The difference is largest in the use of daycare centres, which amounts to $32.8 \%$ of children in Quebec compared to $10.9 \%$ in the rest of Canada.

When examined by family structure (two-parent or one-parent families) and by work status of the survey respondent, which is most likely the child's mother, the differences between Quebec and the rest of Canada remain. In two-parent families, the differences between Quebec and the rest of Canada are large regardless of the work status of the responding parent. For instance, where the responding parent is working full-time, $83.7 \%$ in Quebec and $65.5 \%$ in the rest of Canada make use of child care, with $42.2 \%$ using 
daycare in Quebec and 14.1\% in the rest of Canada. In one-parent families, the differences in child care use between Quebec and the rest of Canada are also significant though not as large as in two-parent families. Where the parent is working full-time, 93.1\% of children in Quebec are receiving care with $50.6 \%$ in daycare, whereas the comparable figures for the rest of Canada are $84.9 \%$ and $32.2 \%$. Where the responding parent is not employed, $29.5 \%$ are in daycare in Quebec compared to $14.8 \%$ in the rest of Canada.

Table 3: Proportion (\%) using Various Care Facilities for Children aged 0-5, Canada, Quebec, and Rest of Canada, 2002/2003

\begin{tabular}{|c|c|c|c|c|c|c|c|}
\hline & \multicolumn{3}{|c|}{ Two Parents } & \multicolumn{3}{|c|}{ One Parent } & \multirow{3}{*}{ Total } \\
\hline & Full Yr & Other & Not & & Other & Not & \\
\hline & Full time & Employec & Employe & Full time & mploye & Employed & \\
\hline $\begin{array}{l}\text { Canada } \\
\text { Using child care } \\
\text { Type of care }\end{array}$ & 70.1 & 55.6 & 16.8 & 86.7 & 66.1 & 33.4 & 52.3 \\
\hline $\begin{array}{l}\text { Someone else's home, } \\
\text { nonrelative }\end{array}$ & 27.9 & 20.0 & 3.4 & 26.7 & 16.7 & 5.5 & 18.4 \\
\hline $\begin{array}{l}\text { Someone else's home, } \\
\text { relative }\end{array}$ & 15.9 & 16.6 & 5.9 & 17.3 & 17.4 & 6.0 & 13.5 \\
\hline $\begin{array}{l}\text { Own home, nonsibling } \\
\text { relative }\end{array}$ & 12.2 & 11.9 & 5.3 & 13.2 & 17.7 & 5.2 & 10.4 \\
\hline Own home, nonrelative & 7.4 & 8.4 & 2.2 & 8.0 & 9.1 & 3.1 & 6.4 \\
\hline Daycare centre & 21.2 & 13.9 & 4.8 & 36.1 & 22.8 & 17.6 & 15.7 \\
\hline Nursery school/preschool & 3.6 & 2.8 & 1.0 & 7.1 & 1.5 & 3.5 & 2.8 \\
\hline Before, after school & 3.0 & 1.4 & 0.5 & 7.7 & 2.7 & 1.9 & 2.1 \\
\hline Other child care arrangement & 2.2 & 1.9 & 0.5 & 3.5 & 2.1 & 1.6 & 1.8 \\
\hline $\begin{array}{l}\text { Own home, child's sibling } \\
\text { Quebec }\end{array}$ & 1.1 & 1.4 & 1.4 & 2.7 & ** & ** & 1.3 \\
\hline $\begin{array}{l}\text { Using child care } \\
\text { Type of care }\end{array}$ & 83.7 & 66.8 & 28.5 & 93.1 & 65.5 & 49.2 & 65.1 \\
\hline $\begin{array}{l}\text { Someone else's home, } \\
\text { nonrelative }\end{array}$ & 28.4 & 20.9 & 4.0 & 21.9 & ** & ** & 19.3 \\
\hline $\begin{array}{l}\text { Someone else's home, } \\
\text { relative }\end{array}$ & 13.6 & 14.1 & 10.4 & 15.1 & ** & $\star \star$ & 12.6 \\
\hline $\begin{array}{l}\text { Own home, nonsibling } \\
\text { relative }\end{array}$ & 8.7 & 10.0 & 6.9 & 10.8 & ** & ** & 8.5 \\
\hline Own home, nonrelative & 9.0 & 7.9 & 1.8 & 9.3 & 7.1 & 8.2 & 7.0 \\
\hline Daycare centre & 42.2 & 33.1 & 13.7 & 50.6 & 32.3 & 29.5 & 32.8 \\
\hline Nursery school/preschool & 3.9 & 5.1 & 1.0 & 2.7 & ** & ** & 3.3 \\
\hline Before, after school & 6.3 & 3.5 & 1.8 & 16.9 & 6.7 & 7.9 & 5.0 \\
\hline Other child care arrangement & $\star \star$ & ** & $* *$ & ** & $* *$ & $\star *$ & 3.8 \\
\hline $\begin{array}{l}\text { Own home, child's sibling } \\
\text { Rest of Canada }\end{array}$ & 0.9 & 1.4 & 1.5 & ** & ** & ** & 1.1 \\
\hline $\begin{array}{l}\text { Using child care } \\
\text { Type of care }\end{array}$ & 65.5 & 53.0 & 13.6 & 84.9 & 66.3 & 29.6 & 48.7 \\
\hline $\begin{array}{l}\text { Someone else's home, } \\
\text { nonrelative }\end{array}$ & 27.7 & 19.9 & 3.3 & 28.0 & 16.7 & 5.7 & 18.2 \\
\hline $\begin{array}{l}\text { Someone else's home, } \\
\text { relative }\end{array}$ & 16.7 & 17.2 & 4.6 & 17.8 & 18.9 & 6.9 & 13.7 \\
\hline $\begin{array}{l}\text { Own home, nonsibling } \\
\text { relative }\end{array}$ & 13.4 & 12.3 & 4.9 & 13.8 & 19.6 & 5.8 & 11.0 \\
\hline Own home, nonrelative & 6.9 & 8.5 & 2.3 & 7.7 & 9.6 & 1.9 & 6.3 \\
\hline Daycare centre & 14.1 & 9.5 & 2.4 & 32.2 & 20.7 & 14.8 & 10.9 \\
\hline Nursery school/preschool & 3.5 & 2.3 & 1.0 & 8.3 & 1.3 & 4.2 & 2.7 \\
\hline Before, after school & 1.9 & 1.0 & 0.1 & 5.3 & ** & ** & 1.3 \\
\hline Other child care arrangement & 1.4 & 1.1 & 0.5 & 3.8 & ** & $\star \star$ & 1.2 \\
\hline Own home by child's sibling & 1.2 & 1.4 & 1.3 & 3.1 & ** & ** & 1.4 \\
\hline
\end{tabular}


The comparisons between Quebec and the rest of Canada show that availability of daycare facilities make a difference in the care for children. A comparison between one-parent and two-parent families shows that a partner in the home also makes a difference in the use of child care facilities. As can be seen in Table 3, for Canada as a whole, there is greater use of care facilities in one-parent families than in two-parent families whatever the work status of the responding parent. For instance, when the parent is working full-time, $70.1 \%$ in two-parent and $86.7 \%$ in one-parent families are using childcare, of whom $21.2 \%$ and $36.1 \%$, respectively, use daycare. When the responding parent is not employed, $33.4 \%$ in one-parent families use child care with more than half $(17.6 \%)$ in daycare centres. In comparison, the corresponding proportions in two-parent families are $16.8 \%$ in child care use and $4.8 \%$ in daycare.

While child care use is much higher in Quebec than in the rest of Canada, regardless of family structure and work status of the responding parent, Table 3 also shows that the differences in the use of child care between two-parent and one-parent families are significantly less in Quebec than in the rest of Canada. For instance, when the responding parent is working full-time, in comparison to two-parent families, daycare use is only $20 \%$ [(50.6\%-42.2\%)/42.2\%] higher in one-parent families in Quebec whereas it is $128 \%$ [(32.2\%-14.1\%)/14.1\%] in the rest of Canada. For responding parents who are working but not on a full-time basis, there is hardly any difference across these family types in Quebec daycare use whereas the difference is $117 \%$ [ $(20.7 \%-9.5 \% 0 / 9.5 \%]$ in the rest of Canada. When daycare is less available, one-parent families are more likely to use the facilities; and thus, when there is greater access, such as in Quebec, the increase in use is greater in two-parent families than in one-parent families.

The National Longitudinal Survey of Children and Youth indicates considerable change in child care. For children aged six months to five years, $41.9 \%$ were in some child care situation in 1994/95 compared to $53.2 \%$ in 2000/01 (Statistics Canada, 2005). The results also show that a quarter of these children are in daycare centres in 2000/01, compared to a fifth in 1994/95, and that daycare use is more common for children of oneparent families.

Clearly, children are in a diversity of care situations. For Canada as a whole, children are more likely to be in care when the mother is working, especially full-time, and when they live with only one parent. In two-parent families, care in someone else's home by a nonrelative is the most common form of care, while daycare most common in one-parent families. In Quebec, daycare is the most common form of care for each of the categories of family type and employment status of the responding parent. 


\section{Parental Preferences for Work}

In addition to factors such as work status of parents (particularly of mothers), family structure, and availability of child care facilities, parental preferences for work and child care also determine the manner of caring for children. However, surveys do not often ask about parental preferences. In particular, the NLSCY has no questions on preferences for work and child care. In the 1988 Child Care Survey, the "designated adult," that is the respondent in the survey who is the person most responsible for child care in the family, was asked "when considering your own needs and those of your family, would you most prefer to work full-time, to work part-time, or not work at a job or business?" This question was only asked of employed respondents, and it found a significant interest to work less than they were currently working (Beaujot, 2000:280). Similarly, asked, "considering everything, what would be the ideal situation for you - working full-time, part-time, or not at all outside the home?" a 2007 American survey finds 21\% of working mothers and $16 \%$ of at-home mothers with children under 18 indicate full-time as the ideal (Pew Research Centre, 2007). The ideal of part-time work is given by $60 \%$ of working mothers and $33 \%$ of at-home mothers.

Preferences on hours of work were also asked in the 1995 Work Arrangements Survey. Persons who were employed were asked if they would prefer to work fewer hours for less pay, more hours for more pay, or stay with the same hours for the same pay. These responses have been classified by the age of the youngest child in the home. As can be seen in Table 4, most would prefer to stay with the same hours, but the proportion opting for fewer hours is highest (at 16.6\%) among women working full-time who have children under 3 years of age. At the same time, the proportion wanting to work more hours for more pay among women working full-time and who have children 3 years and under is almost as high (at 14.7\%) as those wanting to work fewer hours. Furthermore, about a third of the women $(37 \%)$ with children under three years of age who are working part-time prefer to work more hours for more pay.

Work preferences also vary by the presence of a spouse. Among women working full-time, it is those with a spouse who are more likely (at $17.4 \%$ ) to want to work fewer hours for less pay, especially if they have children less than three years of age. In contrast, among women working full-time, who have children younger than three years, but are not living with a spouse, only about $5 \%$ wish to work fewer hours while almost half (47.6\%) prefer to be working more hours.

Except for married women with children under six, other categories in the population have higher proportions who want to work more hours com- 
Table 4: Work Preference (\%) by Sex, Presence of Children, Presence of Spouses and Full-time or Part-time Work Status, Employed Persons aged 15-64, Canada, 1995

\begin{tabular}{|c|c|c|c|c|c|c|}
\hline & \multicolumn{3}{|c|}{ Male } & \multicolumn{3}{|c|}{ Female } \\
\hline & $\begin{array}{l}\text { Fewer } \\
\text { Hours }\end{array}$ & $\begin{array}{l}\text { More } \\
\text { Hours }\end{array}$ & $\begin{array}{l}\text { Same } \\
\text { Hours }\end{array}$ & $\begin{array}{l}\text { Fewer } \\
\text { Hours }\end{array}$ & $\begin{array}{l}\text { More } \\
\text { Hours }\end{array}$ & $\begin{array}{l}\text { Same } \\
\text { Hours }\end{array}$ \\
\hline \multicolumn{7}{|c|}{ Married or Cohabiting, Working Full-time } \\
\hline No child & 8.1 & 21.5 & 70.4 & 9.1 & 17.0 & 73.9 \\
\hline At least one child under 3 & 5.0 & 24.1 & 70.9 & 17.4 & 12.5 & 70.1 \\
\hline Children under 6 & 4.2 & 27.3 & 68.5 & 13.8 & 16.7 & 69.5 \\
\hline Children of older ages & 5.5 & 18.4 & 76.1 & 10.3 & 14.9 & 74.8 \\
\hline Total & 6.1 & 21.3 & 72.6 & 11.1 & 15.6 & 73.4 \\
\hline \multicolumn{7}{|c|}{$\begin{array}{l}\text { Married or Cohabiting, Working Part- } \\
\text { time }\end{array}$} \\
\hline No child & 0.0 & 44.2 & 55.8 & 2.5 & 40.3 & 57.2 \\
\hline At least one child under 3 & 0.0 & 81.1 & 18.9 & 1.2 & 34.4 & 64.5 \\
\hline Children under 6 & 0.0 & 78.9 & 21.1 & 1.5 & 35.4 & 63.1 \\
\hline Children of older ages & 0.0 & 72.5 & 27.5 & 1.1 & 43.2 & 55.8 \\
\hline Total & 0.0 & 60.9 & 39.1 & 1.5 & 40.1 & 58.3 \\
\hline \multicolumn{7}{|l|}{ Other, Working Full-Time } \\
\hline No child & 4.5 & 28.3 & 67.3 & 5.9 & 22.8 & 71.3 \\
\hline At least one child under 3 & 0.0 & 31.6 & 68.4 & 4.8 & 47.6 & 47.6 \\
\hline Children under 6 & 0.0 & 57.1 & 42.9 & 5.4 & 28.4 & 66.2 \\
\hline Children of older ages & 2.0 & 36.1 & 61.9 & 4.4 & 27.8 & 67.8 \\
\hline Total & 3.8 & 30.3 & 65.8 & 5.3 & 25.1 & 69.5 \\
\hline \multicolumn{7}{|l|}{ Other, Working Part-Time } \\
\hline No child & 0.8 & 68.7 & 30.5 & 0.9 & 57.3 & 41.8 \\
\hline At least one child under 3 & 0.0 & 100.0 & 0.0 & 9.5 & 71.4 & 19.0 \\
\hline Children under 6 & 0.0 & 66.7 & 33.3 & 0.0 & 67.6 & 32.4 \\
\hline Children of older ages & 0.6 & 52.1 & 47.2 & 0.9 & 51.4 & 47.7 \\
\hline Total & 0.7 & 57.1 & 42.3 & 1.0 & 53.9 & 45.1 \\
\hline \multicolumn{7}{|l|}{ Total, Working Full-Time } \\
\hline No child & 6.2 & 25.0 & 68.8 & 7.6 & 19.6 & 72.8 \\
\hline At least one child under 3 & 4.9 & 24.3 & 70.9 & 16.6 & 14.7 & 68.7 \\
\hline Children under 6 & 4.3 & 27.8 & 67.9 & 12.5 & 18.5 & 69.0 \\
\hline Children of older ages & 4.7 & 22.2 & 73.1 & 8.5 & 18.9 & 72.6 \\
\hline Total & 5.4 & 24.1 & 70.5 & 9.1 & 18.8 & 72.1 \\
\hline \multicolumn{7}{|l|}{ Total, Working Part-Time } \\
\hline No child & 0.5 & 60.5 & 38.9 & 1.8 & 47.0 & 51.2 \\
\hline At least one child under 3 & 0.0 & 81.8 & 18.2 & 1.8 & 37.0 & 61.2 \\
\hline Children under 6 & 0.0 & 75.0 & 25.0 & 1.3 & 40.0 & 58.8 \\
\hline Children of older ages & 0.6 & 53.7 & 45.7 & 1.0 & 47.4 & 51.6 \\
\hline Total & 0.5 & 57.8 & 41.6 & 1.3 & 45.7 & 53.0 \\
\hline
\end{tabular}

Notes: Fewer hours: fewer hours for less pay

More hours: more hours for more pay

Same hours: same hours for same pay and missing data

Source: Work Arrangements Survey, 1995 
pared to those wanting to work fewer hours. Among persons who are not in relationships, there are high proportions who would want to work more hours, even among persons working full-time, especially for men.

\section{Parental Preferences for Child Care}

Fewer surveys have asked about preferences for child care. The 1988 Child Care Survey asked employed respondents about their preferred form of child care. For those with children under six years of age, $22.4 \%$ would have preferred daycare, however only $12.2 \%$ of children were in the daycare as their main form of care. There is also considerable interest in care by nonrelatives and relatives, either in child's home or in another home (Beaujot, 2000:284).

For further data on parental preferences for child care, we take advantage of a 2000-01 survey from London, Ontario, and the surrounding

Table 5: Views on Benefits and Services for Children by Age Groups London, Ontario, 2000-01

\begin{tabular}{|c|c|c|c|}
\hline \multicolumn{4}{|c|}{ Panel A: Level of support (\%) for various possible government initiatives } \\
\hline & \multicolumn{2}{|c|}{ Age Groups } & \multirow[b]{2}{*}{ All Respondents } \\
\hline & $\begin{array}{l}\text { Less } \\
\text { than } 45\end{array}$ & $\begin{array}{l}45 \text { and } \\
\text { older }\end{array}$ & \\
\hline Inexpensive day care open to families with low income & 90 & 87 & 88 \\
\hline Inexpensive day care open to all families & 75 & 56 & 66 \\
\hline $\begin{array}{l}\text { Direct financial support for low income families with } \\
\text { children }\end{array}$ & 75 & 74 & 75 \\
\hline $\begin{array}{l}\text { Direct financial support for every family with children, } \\
\text { regardless of income }\end{array}$ & 38 & 23 & 30 \\
\hline Extending paid parental leave to two years & 62 & 33 & 49 \\
\hline $\begin{array}{l}\text { Extending paid parental leave but requiring that } \\
\text { parents share the leave }\end{array}$ & 47 & 29 & 39 \\
\hline Introduce leaves for caring for ill relatives & 86 & 78 & 82 \\
\hline $\begin{array}{l}\text { Pay parents who stay home to care for their children } \\
\text { the same amount as it would cost the government to }\end{array}$ & 66 & 49 & 58 \\
\hline
\end{tabular}

Panel B: Personal preference (\%) for one child-related benefit for families with young children

\begin{tabular}{lccc}
\hline & \multicolumn{2}{c}{ Age Groups } & \\
\cline { 2 - 3 } & $\begin{array}{c}\text { Less } \\
\text { than } 45\end{array}$ & $\begin{array}{c}45 \text { and } \\
\text { older }\end{array}$ & All Respondents \\
\cline { 2 - 3 } $\begin{array}{l}\text { More subsidies for parents in the form of family } \\
\text { benefits, family allowance or tax deductions }\end{array}$ & 41 & 47 & 44 \\
Longer parental leave after the child's birth & 34 & 19 & 27 \\
More publicly supported child care facilities & 16 & 20 & 18 \\
None of the above & 10 & 14 & 12 \\
\hline
\end{tabular}

Sources: 2000-01 Survey of attitudes to marriage and child-bearing, London, Oxford, and Middlesex Counties, Ontario. 
region. Respondents were asked about their views on various possible government initiatives, using categories "support, tend to support, tend not to support, do not support." As can be seen in Table 5, for all respondents, the combined proportion of those who "support" and "tend to support" was highest for "inexpensive daycare open to families with low income" (88\%), and next highest, for "direct financial support for low income families with children" (75\%). Inexpensive daycare open to all families is also supported by $66 \%$ of respondents. Only about $30 \%$ support "direct financial support for every family with children, regardless of income." When asked "what one child-related benefit you would personally prefer, for families with young children," the highest preference is for more subsidies for parents in the form of family benefits, family allowance or tax deductions (44\%), followed by longer parental leave after the child's birth (27\%), and by more publicly supported child care facilities (18\%). In comparison to older respondents, the level of support for each of the various initiatives is higher among respondents who are less than 45 years old. There are also more younger respondents (34\%) who prefer "longer parental leave after a child's birth" than among those aged 45 and older (19\%).

\section{Policy Reflections}

The variety of family contexts, based on family structures and life course stages, with the associated diversity of behaviour and preferences of parents, imply a diversity of needs for support from the society. The political discussion in the period of the minority governments since 2004 has been excessively polarized on the alternatives of increased availability of daycare in contrast with direct transfers to families (MacKay, 2006). Given the diversity across families, our basic proposition is for both and, along with a need to enhance the subsidization of parental leave, increase the benefits associated with part-time work, and enhance provisions for lone parents.

In terms of child care services the differences between Quebec and the rest of Canada indicate that services will be used if they are provided at a reasonable cost. The data concerning work behaviour and preferences also indicate that there is a demand for daycare services. Furthermore, on the basis of a small qualitative survey in London, there is support for provision of such services to parents. Jenson (2004) proposes that a paradigm shift is occurring, from the view that children are the responsibility of the parents, to an "investing-in-children" perspective. In the earlier paradigm, families have primary responsibility and the state takes over when the parents are unable to do so. In the social investment paradigm there are financial in- 
ducements to use high quality nonparental child care. Jenson proposes that the two paradigms are currently coexisting, and thus the differential views, with some opting for stronger state involvement in early childhood education and child care. The first budget of the Harper government provided "child-care allowance" of $\$ 1200$ a year for parents of each child under six years of age. Advocates for affordable regulated child care spaces see this provision as inadequate. The OECD (2007) study on Babies and Bosses: Reconciling Work and Family Life also raises the issue that increased availability for middle class families not be at the expense of lower availability for low income families.

Furthermore, child care is but a part of the investment by families and society in children. If we look at gender and family change in terms of both economic and cultural lens, there seems to be an interest in both more equal opportunities at work and considerable parental time with children. Most would seem to prefer an "adaptive" model, as described by Hakim (2003), that is neither work-centred nor family-centred but that allows for both family and work. To enable parents to have the time and resources for both work and children, they need support from broader society that goes beyond daycare, among which are policies related to work and benefits for children and for families in need. Alternatives that would enable parents to look after children themselves include enriched parental leaves, part-time work with good benefits, and subsidies that supplement market incomes.

In terms of parental leave, there has been an increase in the average months of leave as the benefits of employment insurance have been extended to one year from the previous benefit of six months (Marshall, 2003). In 1993-96, for example, $60 \%$ returned within 6 months and $86 \%$ within a year, whereas in 2001 only 24\% returned within 6 months but $77 \%$ within a year (Marshall, 1999; 2003). A more generous system in Quebec, along with specific provisions for fathers, has increased the proportions of both mothers and fathers taking parental leave (Bureau de l'actuaire en chef, 2008). Given that public support for parental leave is paid from Employment Insurance, a two-tiered system has evolved with some having only access to the Employment Insurance benefit, and others having considerable top-up from employers. In support of families, a call for a universal system of parental leave with $75 \%$ of regular pay seems appropriate.

Canada is unique in having no universal benefit for children beyond age 6, either as a family allowance or as a tax deduction. The earlier benefits along these lines were converted into the child tax benefit which is based on income. A case could be made to enrich and extend the child tax benefit so that middle class persons with children have at least some benefit that starts to equalize their standard of living in comparison to people without 
children. The child tax benefits allow parents to spend less of their time in the market and thus to spend more time with young children.

For mothers with children under six years of age, there is also interest in reduced hours of work, as long as these reduced hours come with good benefits. Employers take advantage of part-time workers, in part because they are allowed to discriminate in terms of salary and work benefits.

We also need to enhance our special provisions for lone parents (Beaujot and Liu, 2002). There are currently two provisions that benefit lone parents. One is the equivalent-to-married tax deduction that is granted to the first child of a one-parent family. Another is the $75 \%$ replacement rate for employment insurance in the case of a main breadwinner who has low income and is receiving child tax benefits. These provisions are small compared to some other countries. For instance, Denmark doubles the family allowance for the first child of a one-parent family. Other provisions involve capturing income from the absent parent. While this is clearly important, it does not help if the absent parent is unable to pay or manages to escape making the child support payments. Advance maintenance payments provide a stronger guarantee since they are provided directly by the state to the lone parent, regardless of the extent to which they can be collected from the absent parent.

\section{Conclusion}

The focus on earning and caring highlights both the alternative models of families, and the differential needs for services depending on family structure and life course stage (see Glass and Estes, 1997). In the complementary model of division of work, families can take responsibility for children as long as breadwinners are able to supply the needed income. There is evidence of the persistence of this model in the lower level of work participation of women with young children, especially when they are married rather than cohabiting or post-married. Families who live by this traditional model of the division of work are most interested in workplace benefits that are associated with breadwinners, and in subsidies from the larger society, such as child tax benefits or direct transfers.

Women's high rates of education and labour force participation, particularly among the young, indicate that many opt for a more symmetric division of labour. Depending on the priority attributed to work, some families have preferences for leaves associated with childbirth, and options to work part-time with good benefits when children are young. This is evidenced by the greater preference for fewer hours of work for women with 
children younger than six years of age, especially if they are under three years old. However, there is an almost equal proportion preferring to have more hours of work among these women with young children and who are working full-time, and even higher proportions among women who are working part-time. The options for child care are clearly most important here, especially for couples where both partners see themselves as continuous full-time participants in the labour force. Provisions for child care, along with other supports for work-life balance would probably increase the numbers of couples who opt for a symmetric model of the division of work (Reynolds, 2007:356).

The situation is very different for women in one-parent families who are doing less market work and are more likely to prefer working more hours for more pay, even when they have young children. These women have fewer options for division of paid and unpaid work, and thus are the most likely to be using child care facilities, especially daycare centres. Lone parents clearly need further support from society, and the special provisions that we have now are inadequate, especially in cases where absent parents are unwilling or unable to provide support. A case can be made for a guaranteed amount of support from the state, which could take the forms of higher replacement rates for parental leave, higher child tax benefits, greater subsidies for child care, but also advance maintenance payments that would give a guaranteed amount regardless of the contributions from absent parents.

The needs of families, in terms of support from the broader society, thus depend on family structure and on the model that they adopt for the division of paid and unpaid work. This support must include education and child care services, but also important are leaves and opportunities for parttime work with good benefits that would allow parents to fulfil their desires to look after young children themselves, and other subsidies and direct transfers that would reduce the need for market income during the early parenthood stage. As we move toward an "investing-in-children" paradigm, and a more symmetrical model for the sharing of paid and unpaid work, early childhood education and child care gain higher priority.

\section{References}

Beaujot, Roderic. 2000. Earning and Caring in Canadian Families. Peterborough, ON: Broadview.

Beaujot, Roderic and Jianye Liu. 2002. "Children, social assistance and outcomes: cross-national comparisons.” Pp. 179-203 in proceedings of conference of the Federation of 
Canadian Demographers, Demographic Futures in the Context of Globalization: Public Policy Issues. Ottawa: Federation of Canadian Demographers.

2005. "Models of time use in paid and unpaid work." Journal of Family Issues 26:924 946.

Beaujot, Roderic, Zenaida Ravanera, and Jianye Liu. 2008. "Models of earning and caring: Trends, determinants, implications.” Paper prepared for Human Resources and Social Development Canada.

Becker, Gary. 1991. A Treatise on the Family. Enlarged edition. Cambridge, MA; London: Harvard University Press.

Boothby, Daniel and Torbed Drewes. 2006. "Postsecondary education in Canada: Returns to university, college and trades education.” Canadian Public Policy 32(1):1-21.

Bouchard, Brigitte and John Zhao. 2000. "University education: Recent trends in participation, accessibility and returns." Education Quarterly Review 6(4):24-32.

Bureau de l'actuaire en chef. 2008. Rapport sur le portrait de la clientèle du Régime québécois d'assurance parentale 2006. Quebec: Conseil de gestion de l'assurance parentale.

Coltrane, Scott. 1995. "The future of fatherhood." In William Marsiglio, ed., Fatherhood. Thousand Oaks, CA: Sage.

Cook, Cynthia and Roderic Beaujot. 1996. "Labour force interruptions: The influence of marital status and presence of young children." Canadian Journal of Sociology 21(1):25-41

Drolet, Marie. 2002a. Wives, Mothers and Wages: Does Timing Matter? Ottawa: Statistics Canada Cat. No. 11F0019 No. 186.

2002b. "The male-female wage gap." Perspectives on Labour and Income 14(1):29_ 35 .

2003. "Motherhood and paycheques." Canadian Social Trends 68:19-21.

Engelhardt, Henriette and Alexia Prskawetz. 2004. "On the changing correlation between fertility and female employment over space and time." European Journal of Population 20:35-62.

Fox, Bonnie. 2001. "The formative years: How parenthood creates gender." Canadian Review of Sociology and Anthropology 38(4):373-390.

Fox, Bonnie and Doreen Fumia. 2001. "Pathbreakers: Some unconventional families of the nineties.” Pp. 458-469 in B.J. Fox, ed., Family Patterns and Gender Relations. Toronto: Oxford University Press.

Galarneau, Diane. 2006. "Education and income of lone parents." Perspectives on Labour and Income 18(1):7-18.

Glass, Jennifer and Sarah Estes. 1997. "The family responsive workplace.” Annual Review of Sociology 23:289-313.

Hakim, Catherine. 2003. "A new approach to explaining fertility patterns: Preference theory." Population and Development Review 29(3):349-74.

Hochschild, Arlie Russell. 1989. The Second Shift. New York: Viking. 
Hrdy, Sarah Blaffer. 2006. "Meet the alloparents. Interview with Liz Else." New Scientist 190(2546):50-51.

Jenson, Jane. 2004. "Changing the paradigm: Family responsibility or investing in children." Canadian Journal of Sociology 29(2):169-192.

Kaplan, Hillar. 1997. "The evolution of the human life course." Pp. 175-211 in K. Wachter and C. Finch, eds., Between Zeus and the Salmon: The Biodemography of Longevity. Washington: National Academy Press.

Lahdenpera, Mirkka, Virpi Lummaa, Samuli Helle, Marc Tremblay, and Andrew Russell. 2004. "Fitness benefits of prolonged post-reproductive lifespan in women." Nature 428:178-181.

Le Bourdais, Céline and Evelyne Lapierre-Adamcyk. 2004. "Changes in conjugal life in Canada: Is cohabitation progressively replacing marriage?" Journal of Marriage and the Family 66:929-942.

Lee, Ronald D. and Karen L. Kramer. 2002. "Children's economic roles in the Maya family life cycle: Cain, Caldwell, and Chayanov revisited." Population and Development Review 28(3):475-499.

Lundberg, Shelly and Elaina Rose. 2000. "Parenthood and the earnings of married men and women." Labour Economics (November):689-710.

Luxton, Meg. 1980. More than a Labour of Love. Toronto: Women's Press.

Marshall, Katherine. 1996. “A job to die for.” Perspectives on Labour and Income 8:26-31. 1999. "Employment after childbirth.” Perspectives on Labour and Income 11(3):18-25. 2003. "Parental leave: More time off for baby." Canadian Social Trends 71:13-18.

MacKay, Allan. 2006. "Keep your eye on 'family' issues." The Globe and Mail, 9 January 2006, p. A13.

Morissette, René. 1998. "The declining labour market status of young men.” In M. Corak, ed., Labour Markets, Social Institutions and the Future of Canada's Children. Ottawa: Statistics Canada, cat. no. 89-553.

Neill, Ghyslaine. 2004. "Economic conditions, parental employment and childcare in Quebec: Families in a changing world." Paper presented at Conference on Child Care for a Change, Winnipeg, November 2004.

Nevitte, Neil. 1996. The Decline of Deference. Peterborough, ON: Broadview.

Oppenheimer, Valerie Kincade. 1988. "A theory of marriage timing." American Journal of Sociology 94:563-591.

1997. "Women's employment and the gain to marriage." Annual Review of Sociology 23:431-453.

Pew Research Centre. 2007. "From 1997 to 2007: Fewer mothers prefer full-time work." Pew Research Center: A Social \& Demographic Trends Report.

Picot, Garnett. 1998. "What is happening to earnings inequality and youth wages in the 1990s?" Canadian Economic Observer. Ottawa: Statistics Canada, September 3.1-3.18. 
Ranson, Gillian. 1998. "Education, work and family decision making: Finding the right time to have a baby." Canadian Review of Sociology and Anthropology 35(4):517-33.

2005. "No longer 'one of the boys': Negotiations with motherhood, as prospect or reality among women in engineering." Canadian Review of Sociology and Anthropology 42(2):145-166.

Ravanera, Zenaida R. and Fernando Rajulton. 2006. "Social status polarization in the timing and trajectories to motherhood." Canadian Studies in Population 33(2): 179-207.

Reynolds, Jeremy. 2007. “The forum mailbox.” Sociological Forum 22(3):356-357.

Risman, Barbara and Danette Johnson-Sumerford. 1998. "Doing it fairly: A study of postgender marriages.” Journal of Marriage and the Family 60:23-40.

Royal Commission on the Status of Women. 1970. Report. Ottawa: Queen`s Printer.

Statistics Canada. 2005. "Child care.” The Daily 7 February 2005.

Sweeney, Megan. 2002. "Two decades of family change: The shifting economic foundations of marriage." American Sociological Review 67:132-147. 
